Journal of Engineering and Applied Sciences 14 (16): 5847-5853, 2019

ISSN: 1816-949X

(C) Medwell Journals, 2019

\title{
Confinement Effect in Castellated Steel Beams Strengthened by High Strength Concrete and Lacing Reinforcement
}

\author{
Shakir Mahmood Hadeed and Ahmad Jabbar Hussain Alshimmeri \\ Department of Civil Engineering, University of Baghdad, Baghdad, Iraq
}

\begin{abstract}
Use of castellated steel beams for different structural purposes now a days is widespread. The principal useful of castellated steel beams is to enhanced strength due to increasing depth of beam section without any increasing in weight. In this study, steel IPE200 standard section was used to fabricate six specimens with expanded castellated section with and without strengthening by high strength concrete and laced reinforcement within the two side of their webs. Experimental test was achieved to investigate failure load and mid-span section by applying two-point load on beam surface having simple support condition. The experimental results show that the load carrying capacity and the deflection values at ultimate load in the mid-span section were increased for all strengthened beams compared with reference beam. Abaqus 6.14 Software was used to carry out the numerical modeling for tested beams. It was noted that there is good agreement between numerical and experimental results.
\end{abstract}

Key words: Castellated steel beam, ultimate load, deflection, strengthening by high strength concrete and laced reinforcement, finite element analysis, numerical modeling

\section{INTRODUCTION}

Castellated steel beam is expanded beam manufacturing by expanding standard rolled sections in a method which produce a uniform shape of openings. The castellated beam is made from steel I-section beam by cutting its webs longitudinally in a zigzag pattern then separation and removed the two part of the beam and then, rejoin and welding the two parts together as shown in Fig. 1. The castellated beams are widely used in melty story buildings and large span space structures (AISC., 2016).

Scope and objectives: There are many situations in which it is necessary to increase the capacity of structures in use. In conventional I-steel section and castellated steel beams section, the strength of I-steel section is substantial and important. The three constituent materials are combined in a manner maximizing their own advantages which enables confined concrete castellated steel beams section to possess superior performance over existing beam forms including excellent ductility, corrosion resistance and ease for construction.

The objective of this study is the enhancement of the load carrying capacity of castellated steel beams by confinement the section by high strength concrete and lacing reinforcement and study the serviceability of the confined castellated steel beams exposed to static loading.

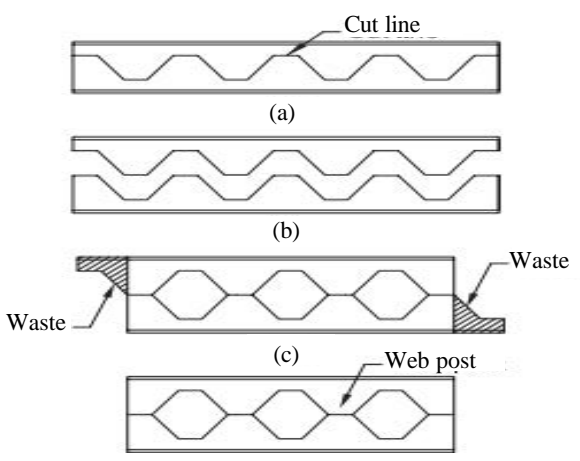

Fig. 1: Manufacturing process of castellated steel beam

Mode of failure: Demirdjian(1999) determine the following possible modes of failure for castellated steel beams:

- Vierendeel or shear mechanism

- Flexural mechanism

- Lateral torsional buckling

- Rupture of the welded joint in a web post

- Shear bucking of a web post

- Compression bucking of a web post

Literature review: Redwood and Demirdjian (1998) studied examine the buckling of the web post between holes by testing twelve castellated beams manufacturing from $8,10,12$ and 14-inch height steel beams section. The six beams have plates with 2-inch height welded between 
the two beam parts at the web-post mid-height of the castellated beam. Maximum load capacities of the samples were adopted to record ultimate strengths. Web post buckling was noticed in 10 cases of failure and local buckling of the tee-section upper the holes exposed to maximum bending moment was noticed in two cases. The two lateral tensional buckling failure were also noticed, finite element analysis was employed to portend web-post buckling load.

Budi and Partono (2017) studied the effect of size and distance of castellated steel beams with hexagonal web openings. The analysis of results show that the capacity of specimens increases by $1.938-2.041$ compare to original section. The best results from FEM analysis was a specimen with $60^{\circ}$ angle and the distance between holes was $0.186-0.266$ ho

Jamadar and Kumbhar (2014) studied the flexural behavior of castellated steel beam by using finite element analysis (Abaqus). The found that important to check the local failure of castellated beam because of lack of shear transfer area, therefore, it is necessary to optimize between size and shape of holes and finite element analysis by using Abaqus Software give good agreement with the results calculated by Indian standards method analysis.

Ismail et al. (2014) studied the influence of different parameters (cross-section dimensions, length of beam, using of stiffeners, concrete strength, steel strength and concrete slab dimension) on both ultimate behavior of composite castellated steel beam and buckling load Abaqus program was used.

They found that the loading capacity of the composite castellated steel beam was raised by using vertical stiffeners. When steel and concrete strength increase, the ultimate load and ductility increase and when concrete slab thickness increase, ultimate load also increase.

\section{MATERIALS AND METHODS}

Materials used in experimental work are:

- Coarse aggregate

- Admixtures

- Fine aggregates

- Cement

- Steel w-shape

- Steel reinforcement bar

The mechanical properties of materials are sorted in Table 1. Concrete materials are tested according to the
Table 1: The mechanical properties of used materials

\begin{tabular}{|c|c|c|c|}
\hline Materials & Strength (MPa) & Modulus of elasticity (MPa) & Poisson ratio \\
\hline Steel beam & $\mathrm{f}_{\mathrm{y}}=359$ & 210000 & 0.3 \\
\hline $\begin{array}{l}\text { Reinforcement } \\
\text { bar }\end{array}$ & $f_{y}=443$ & 200000 & 0.3 \\
\hline Concrete & $\mathrm{f}_{\mathrm{c}}^{\prime}=67.624$ & 38896 & 0.2 \\
\hline \multicolumn{4}{|c|}{$\begin{array}{l}\mathrm{f}_{\mathrm{y}} \text { : Steel materials yield strength }(\mathrm{MPa}), \mathrm{f}_{\mathrm{c}}{ }_{\mathrm{c}} \text { concrete compressive strength } \\
(\mathrm{MPa})\end{array}$} \\
\hline \multicolumn{4}{|c|}{ Table 2: Concrete mix proportions } \\
\hline \multicolumn{3}{|l|}{ Variables } & Values \\
\hline \multicolumn{3}{|l|}{ Sand } & 810 \\
\hline \multicolumn{3}{|l|}{ Gravel $\left(\mathrm{kg} / \mathrm{m}^{3}\right)$} & 850 \\
\hline \multicolumn{3}{|l|}{ Cement $\left(\mathrm{kg} / \mathrm{m}^{3}\right)$} & 600 \\
\hline \multicolumn{3}{|c|}{ Water/binder ratio } & 30 \\
\hline \multicolumn{3}{|l|}{ Water $\left(\mathrm{kg} / \mathrm{m}^{3}\right)$} & 180 \\
\hline \multicolumn{3}{|l|}{ Silica $(\%)$} & 10 \\
\hline \multicolumn{3}{|c|}{ Super plasticizer (\%) } & 2 \\
\hline
\end{tabular}

Iraq Standard Specifications (IQS) No.45/1984 while steel beam coupons and reinforcement bars are tested according to ASTM $(2006,2010)$, respectively. High strength concrete was used with self-compact technique, the mix proportions for concrete materials are shown in Table 2 .

\section{RESULTS AND DISCUSSION}

Hot-rolled standard section IPE 200 was used as the root section to fabrication six samples of castellated steel beams Fig. 2. All beams have span length of $3192 \mathrm{~mm}$ simple support conditions.

Dimensions details and section parameters were shown in Table 3 which were choose agree with the design standards (Knowles, 1985). Types and dimensions of fabricated specimens used in this work are shown in Fig. 3.

From the experimental results it was observed that deflections at mid-span for all strengthened beams increased due to increasing in their ductility compared with reference specimen, noting that specimen 5 and 6 having less deflection than other strengthened specimens (2-4) due to increasing their stiffness resulting from increasing their section height while load carrying capacity was increased for all strengthened specimen compared with reference specimen as shown in Fig. 4 and 5 .

Numerical modeling and results: A six specimens with six deferent configurations were modeled using Abaqus 6.14 finite element system to study the structural behavior of tested specimens. A 3D solid elements type (C3D8R) with reduced integration were used to simulate steel beams and concrete which are suitable for modeling 3D solid structures (Eloboody, 2014) while a two node linear 
Table 3: Specimens dimension details (mm)

\begin{tabular}{|c|c|c|c|c|c|c|c|}
\hline \multirow[b]{2}{*}{ Specimen No. } & \multicolumn{7}{|c|}{ Section parameters } \\
\hline & $\mathrm{e}$ & b & d & tw & $\mathrm{tf}$ & $\mathrm{s}$ & ho \\
\hline$a-d$ & 76 & 57 & 300 & 6 & 8 & 266 & 183 \\
\hline $\mathrm{e}$ & 76 & 57 & 320 & 6 & 8 & 266 & 213 \\
\hline f & 76 & 57 & 350 & 6 & 8 & 266 & 243 \\
\hline
\end{tabular}

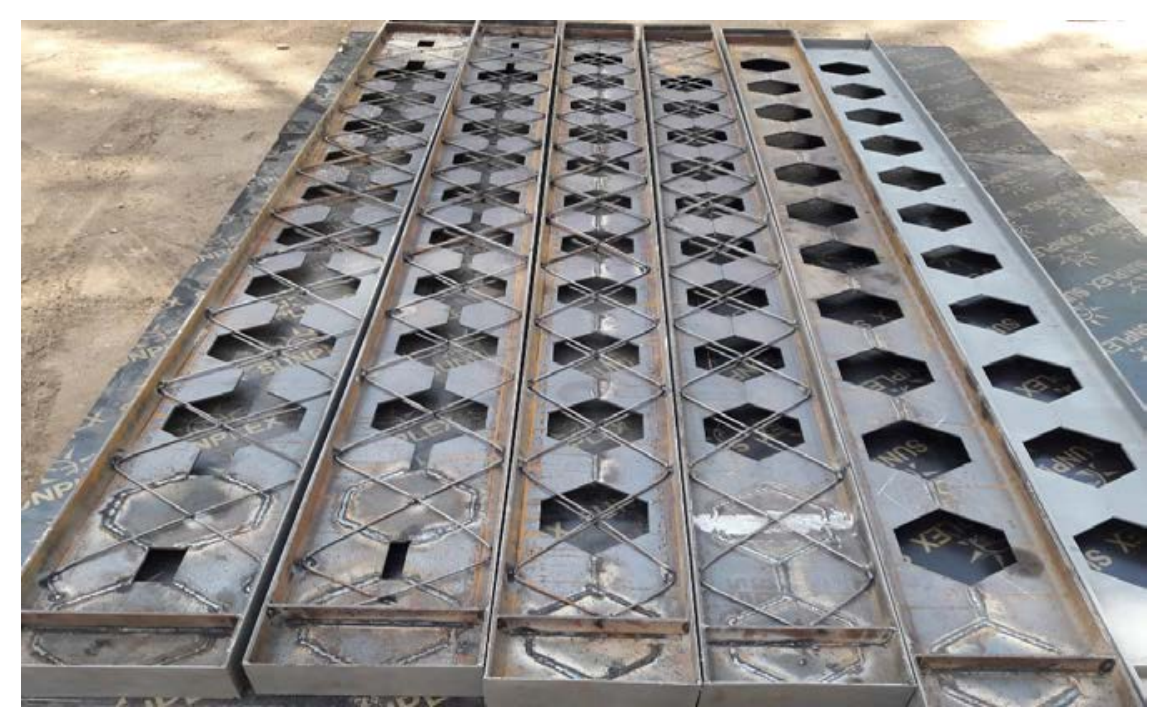

Fig. 2: Fabricated castellated steel beams
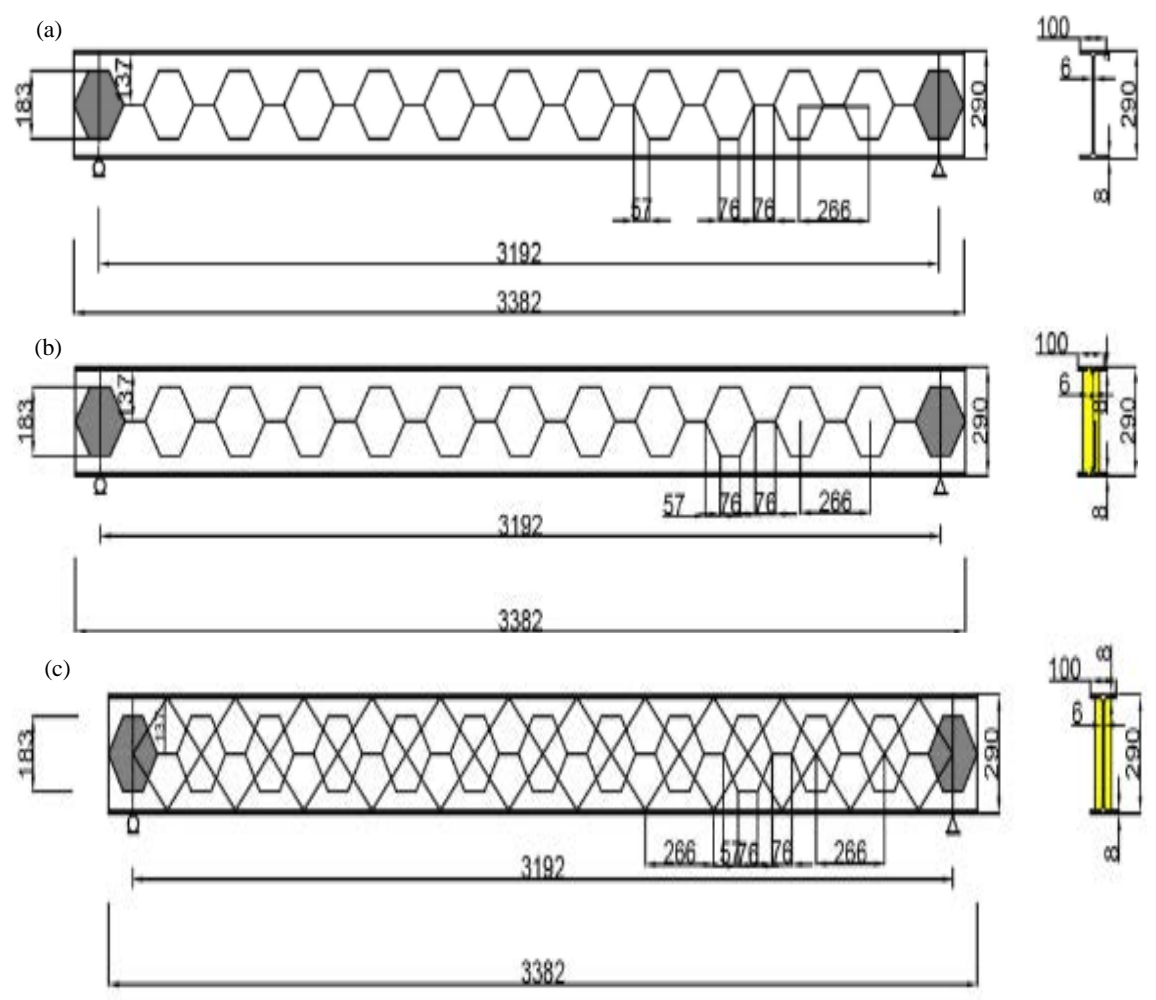

Fig. 3: Continue 
(d)
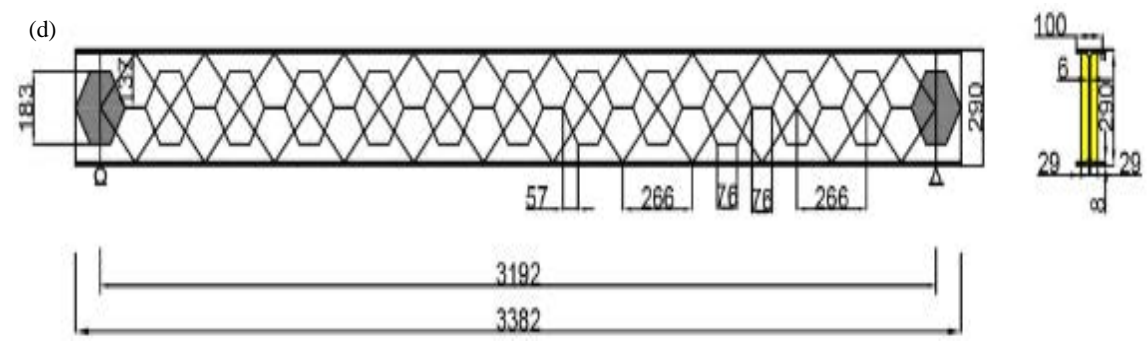

(e)
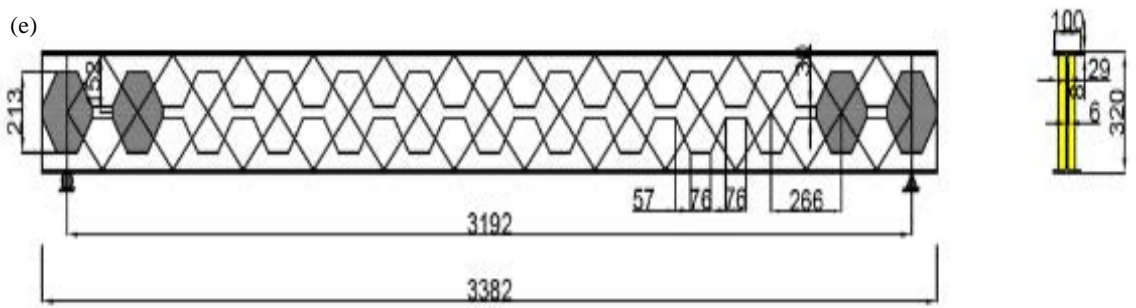

(f)
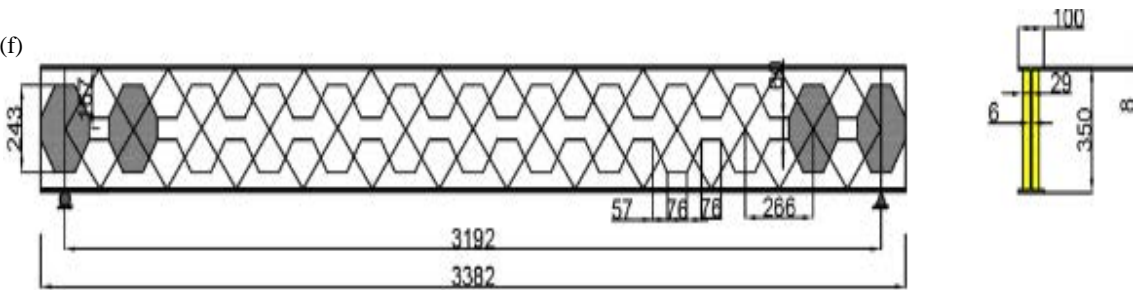

Fig. 3: Dimension details of castellated steel beams and sections, all dimensions in (mm): a) Specimen 1: without strengthening (reference specimen); b) Specimen 2: confined with high strength concrete; c) Specimen 3: confined with high strength concrete and laced reinforcement; d) Specimen 4: confined with highstrength concrete and laced reinforcement without welding 2 parts of castellated beam; e) Specimen 5: confined with high strength concrete and laced reinforcement with increasing the depth of the beam by $10 \%$ and $f$ ) Specimen 6 : confined with high strength concrete and laced reinforcement with increasing the depth of the beam by $20 \%$

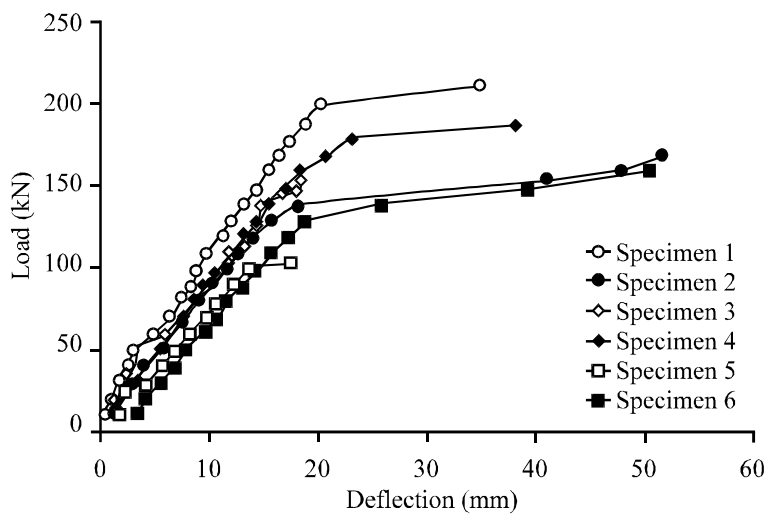

Fig. 4: Load-deflection curves on mid-span section at ultimate load

3D truss elements (T3D2) were used to simulate laced reinforcement. The contacts between surfaces were simulated using tie interaction for steel and concrete and embedded interaction between laced reinforcement and

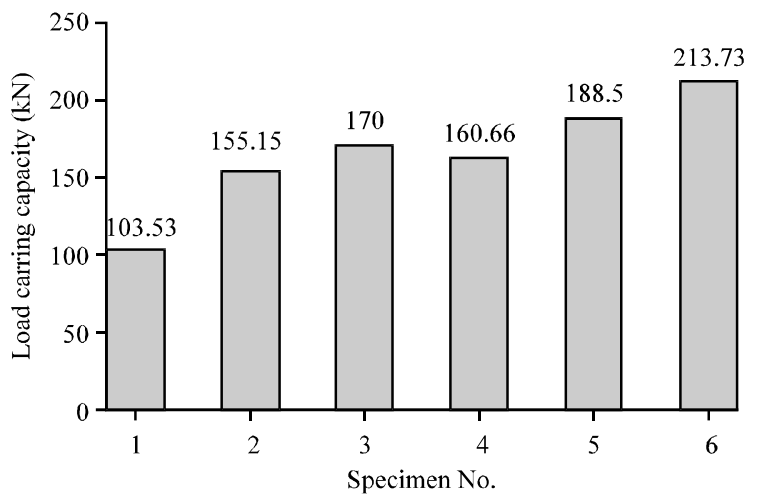

Fig. 5: Load carrying capacity for tested specimens

whole beam. Figure 6 show the modeling of reference beam. The numerical and experimental results of mid-span section deflection at ultimate load and load carrying capacities for all beams are shown in Fig. 7 and 8, respectively also the experimental and numberical ultimate load and mid-span deflection results are listed in Table 4. 
(a)

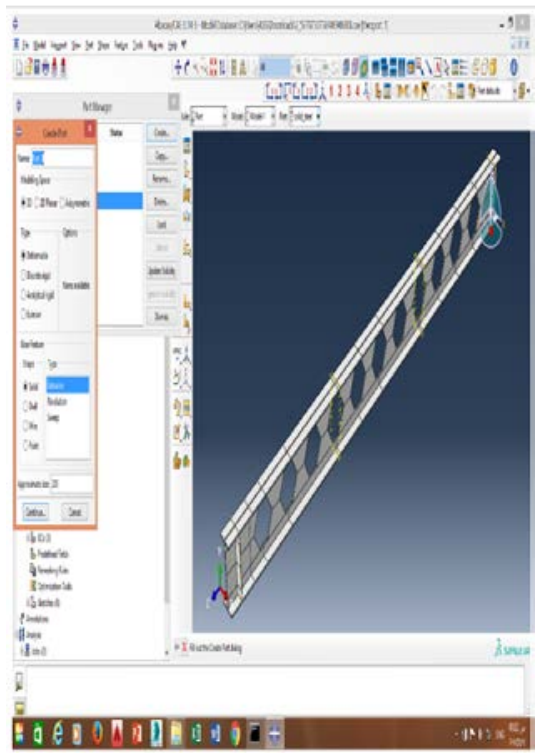

(b)

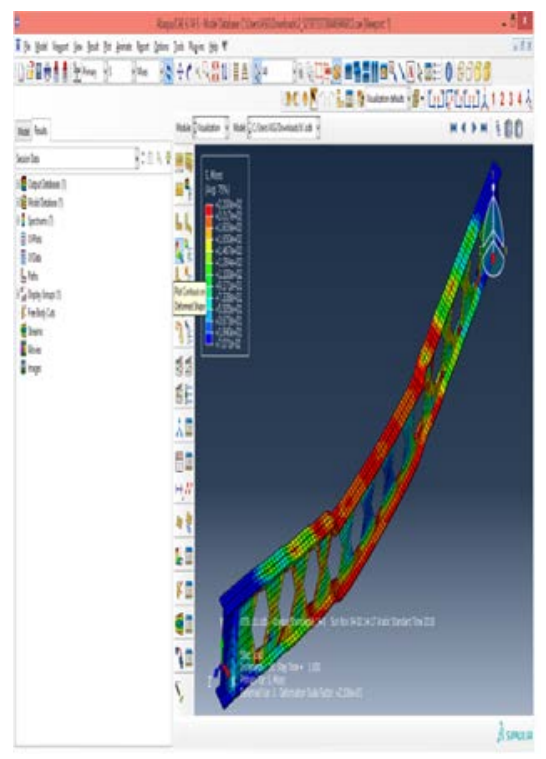

Fig. 6: Finite element modeling and deformed shape for reference beam: a) Beam modeling and b) Deformed shape
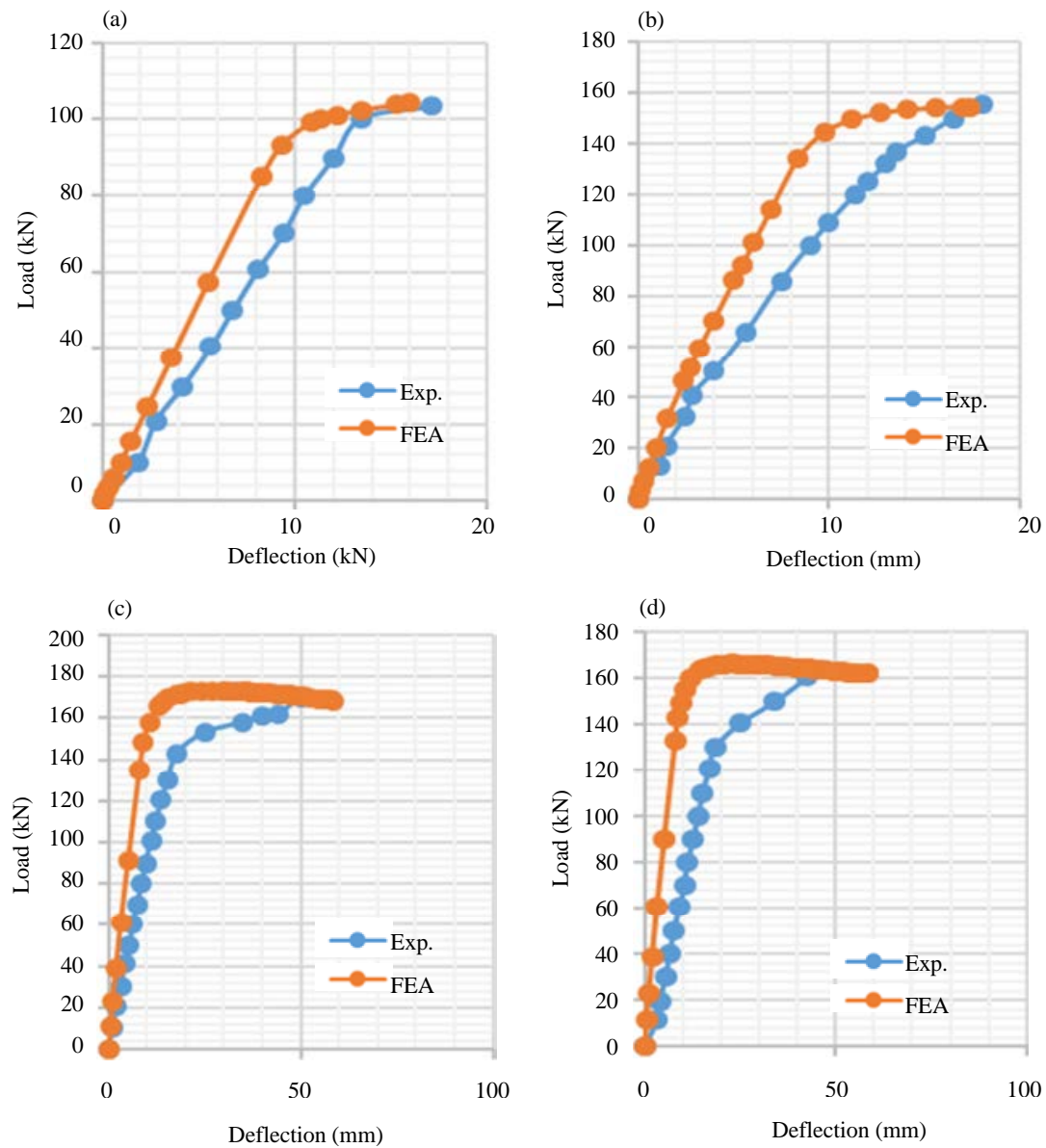

Fig. 7: Continue 

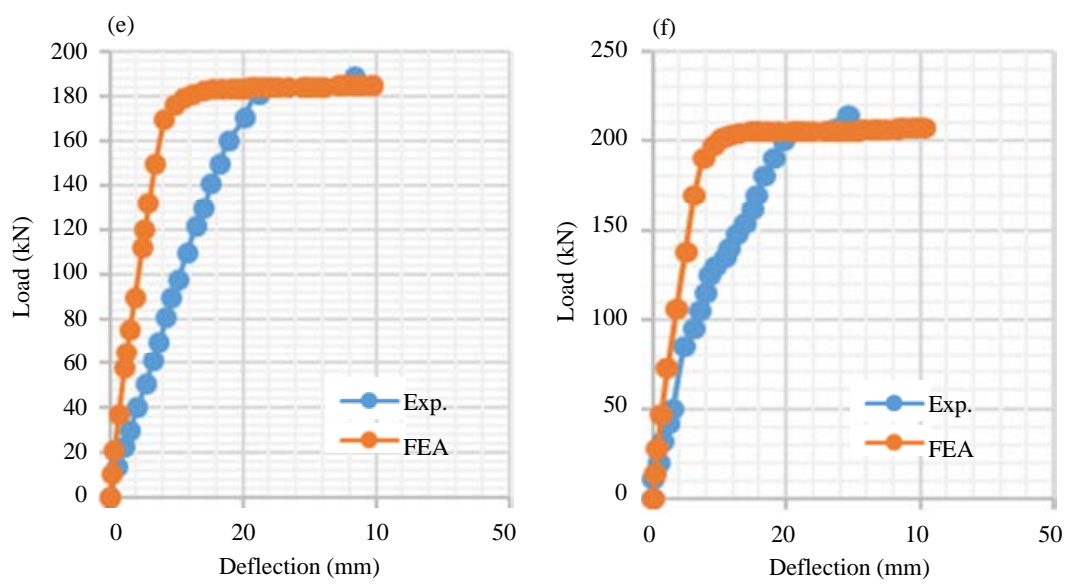

Fig. 7: Numerical and experimental load-deflection curves at mid-span section for all tested specimens: a) Specimen 1;

b) Specimen 2; c) Specimen 3; d) Specimen 4; e) Specimen 5 and f) Specimen 6

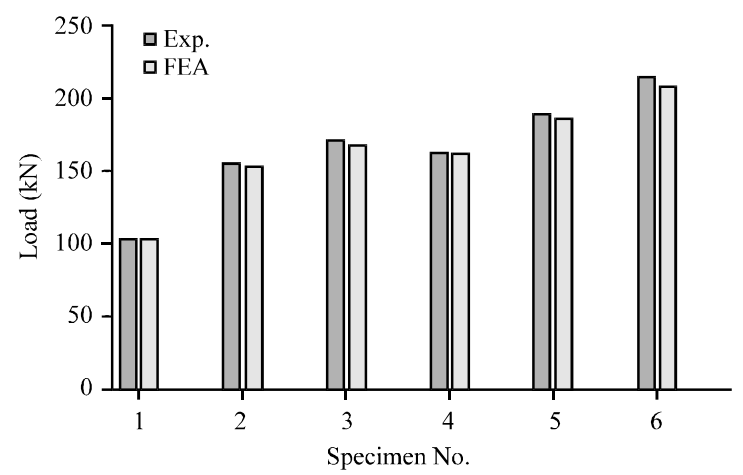

Fig. 8: Numerical and experimental load carrying capacities for tested specimens

\begin{tabular}{|c|c|c|c|c|c|c|}
\hline \multirow[b]{2}{*}{ Variables } & \multicolumn{6}{|c|}{ Specimen No. } \\
\hline & 1 & 2 & 3 & 4 & 5 & 6 \\
\hline \multicolumn{7}{|c|}{ Maximum deflection (mm) } \\
\hline Exp. & 17.12 & 18.00 & 50.00 & 49.00 & 36.92 & 34.00 \\
\hline FEA & 16.00 & 17.39 & 58.00 & 58.00 & 39.60 & 40.00 \\
\hline \multicolumn{7}{|c|}{ Ultimate load (kN) } \\
\hline Exp. & 103.53 & 155.15 & 170.00 & 160.66 & 188.50 & 213.73 \\
\hline FEA & 104.30 & 154.46 & 168.58 & 161.80 & 185.14 & 207.29 \\
\hline
\end{tabular}

\section{CONCLUSION}

Based on numerical and experimental results obtained in this study, it can be concluded the following: mid-span deflection at ultimate load increased from (5.14-192.06\%) for strengthened specimens compared with the reference specimen due to increasing of beams ductility in present of different strengthening techniques.

Load carrying capacity for specimen No. (2-6) was enhanced by $(49.86,64.2,55.18,82.07$ and 106.44$) \%$, respectively, for all specimens strengthened by concrete only or/and concrete and laced reinforcement compared with reference specimen. Good agreement was get between experimental and numerical results.

\section{ACKNOWLEDGEMENTS}

The researchers wish to thank the University of Baghdad, Iraq for the financial support to complete this research and for the help and support submitted by the Civil Engineering Department.

\section{REFERENCES}

AISC., 2016. Castellated and Cellular Beam Design Steel Design Guide-31. 14th Edn., American Institute of Steel Construction Inc., USA.

ASTM., 2006. A370-10 Standard Test Methods and Definitions for Mechanical Testing of Steel Products. ASTM International, West Conshohocken, Pennsylvania, USA., Pages: 47.

ASTM., 2010. A615/A615Mel Standard specification for deformed and plain carbon-steel bars for concrete reinforcement. ASTM International. West Conshohocken, Pennsylvania, USA. https://www. astm.org/Standards/A370

Budi, L. and W. Partono, 2017. Optimization analysis of size and distance of hexagonal hole in castellated steel beams. Procedia Eng., 171: 1092-1099.

Demirdjian, S., 1999. Stability of castellated beam webs. Ph.D Thesis, McGill University Library, Montreal, Quebec, Canada. 
Ismail, R.E.S., A.S. Fahmy and N.M. Tawfik, 2014. Ultimate behavior of composite castellated beams under vertical loads. Intl. J. Comput. Appl., 108: 40-46.

Jamadar, A.M. and P.D. Kumbhar, 2014. Finite element analysis of castellated beam: A review. Intl. J. Innovative Res. Adv. Eng., 1: 125-129.
Knowles, P.R., 1985. Design of Castellated Beams: (For use with BS 5950 and BSAA9). The Steel Construction Institute, Ascot, UK., Pages: 54.

Redwood, R. and S. Demirdjian, 1998. Castellated beam web buckling in shear. J. Struct. Eng., 124: 1202-1207. 